\title{
Pengembangan Media Pembelajaran Pengukuran Listrik Berbasis "Augmented Reality" pada Mahasiswa Teknik Elektro UNIPMA
}

\author{
Yussi Anggraini, Ina Sunaryantiningsih \\ Universitas PGRI Madiun, Indonesia
}

anggraini.yussi@yahoo.com

\begin{abstract}
Penggunaan media pembelajaran yang interaktif sangat membantu dalam proses pembelajaran. Tujuan penelitian ini adalah mengembangkan media pembelajaran "augmented reality" pada mahasiswa Teknik elektro UNIPMA. Rancangan dalam penelitian ini menggunakan pendekatan pengembangan (Iresearch and development). Prosedur penelitian dan pengembangan menurut model ADDIE. Pengembangan media pembelajaran dilakukan melalui beberapa tahap di antaranya: analisis, desain produk, kemudian dilakukan pengembangan produk, implementasi produk dan terakhir evaluasi produk. Populasi dalam penelitian ini berjumlah 22 mahasiswa program studi Teknik elektro. Metode pengumpulan data adalah dokumentasi dan kuesioner. Data hasil penelitian menggunakan teknik analisis deskriptif. Hasil penelitian menunjukkan bahwa media pembelajaran berbasis "augmented reality" termasuk kategori sangat layak untuk membantu proses pembelajaran pada mahasiswa teknik elektro. Berdasarkan hasil penelitian tersebut maka dapat disimpulkan bahwa penggunaan media pembelajaran berbasis augmented reality layak digunakan dalam kegiatan proses pembelajaran pengukuran listrik pada mahasiswa Teknik elektro.
\end{abstract}

Kata Kunci: Augmented reality, Pengukuran listrik, media pembelajaran

\section{Pendahuluan}

Perkembangan teknologi dan informasi saat ini sangat berkembang sangat pesat. Proses pembelajaran tidak lepas dari penggunaan media pembelajaran yang menjadi pendukung saat proses belajar sehingga teknologi komputer memiliki peran yang sangat penting dalam membantu menyelsaikan persoalan pekerjaan manusia dan salah satu teknologi komputer yang sedang berkembang saat ini adalah Augmented Reality (AR) [Maulana, 2014 Rusnandi (2015)]. Metode pembelajaran pengukuran listrik yang digunakan saat ini masih konvensional. Penyampaian materinya masih mempergunakan media seperti papan tulis 
beserta gambar-gambar di buku, sehingga siswa sulit membayangkan komponen-komponen elektro yang akan dipelajari.

Membangun sebuah media pembelajaran yang interaktif bagi mahasiswa dalam mempelajari teori pengukuran listrik dapat dilakukan dengan mengenalkan media pembelajaran yang berbeda. Teknologi Augmented Reality (AR) merupakan teknologi yang memungkinkan penambahan citra sintetis ke dalam lingkungan nyata yang mengizinkan penggunanya berinteraksi secara lebih real-time ke sistem [ Wulansari (2013), Youlia (2013), Ananda (2015)]. Secara sederhana AR bisa didefinisikan sebagai lingkungan nyata yang ditambahkan obyek virtual.

Berdasarkan hal tersebut diharapkan dengan aplikasi ini mahasiswa tidak memerlukan alat praktek yang sesungguhnya untuk digunakan dalam pembelajaran, dengan resiko terjadinya kerusakan pada peralatan komponen tersebut dan mampu meningkatkan kemudahan dalam belajar pada mahasiswa. Hal ini sesuai dengan hasil peneltian bahwa model pembelajaran berbasis Augmented Reality yang dijadikan sebagai media pembelajaran ini mampu menciptakan suasana baru yang lebih interaktif dalam pembelajaran [Siswanto (2013, Rusnandi (2015) \& Burhanudin (2017)]. Dengan bertambahnya media pembelajaran yang interaktif diharapkan Augmented Reality diharapkan dapat digunakan sebagai salah satu alternatif media pembelajaran untuk mengenalkan komponen elektronik yang mampu membuat siswa tertarik dan semangat dalam belajar

\section{Metode penelitian}

Rancangan penelitian ini menggunakan pendekatan R\&D (Research and Development) untuk mengembangkan media pembelajaran berbasis Augmented Reality yang mengacu pada Sutopo (2003) bahwa metodologi pengembangan multimedia terdiri dari 6 tahapan, yaitu concept, design, material collecting, assembly, testing dan distribution Subyek penelitian adalah mahasiswa Teknik Elektro UNIPMA. Instrumen yang digunakan adalah angket dan dokumentasi. Instrumen angket digunakan untuk mengetahui tentang isi dari media tersebut apakah relatif mudah dipahami atau tidak.

\section{Hasil Penelitian}

Hasil penelitian yang dipaparkan terdiri dari beberapa hal di antaranya adalah: hasil media pengembangan Augmented Relaity, hasil uji validitas dan reliabilitas, dan hasil uji coba terhadap responden. Berikut adalah pemaparan hasil media pengembangan AR.

a. scene cover aplikasi.

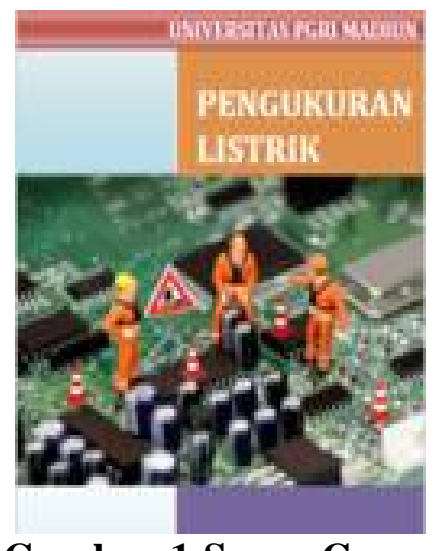

Gambar 1 Scene Cover 
b. ; Scene Main Menu

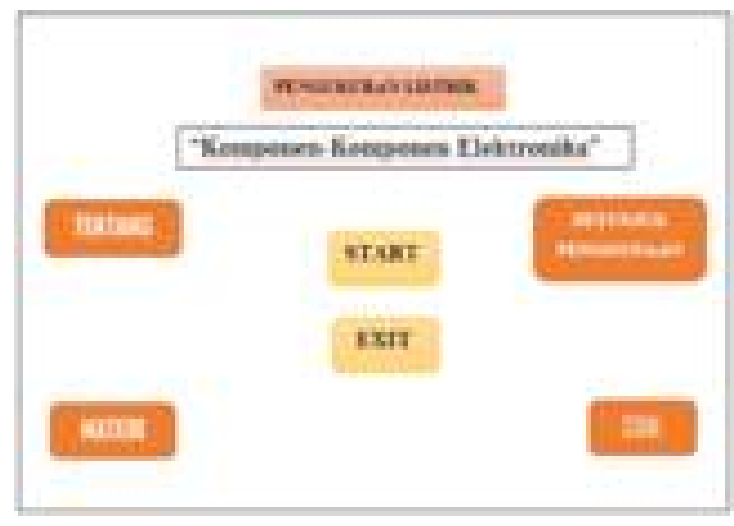

\section{Gambar 2 Scene Main menu}

Berdasarkan Gambar 4.2 diketahui bahwa pada Scene ini terdapat 6 tombol yang memiliki fungsi berbeda yakni: tombol Start untuk memulai aplikasi, tombol Exit untuk mengakhiri aplikasi, tombol Tentang untuk menjelasan pembuat aplikasi, menu Materi untuk digunakan melihat materi yang akan dipelajari, menu Petunjuk Penggunan digunakan untuk memberikan arahan bagaimana cara menggunakan aplikasi tersebut dan juga tombol Soal yaitu untuk menguji keterserapan ilmu yang kita peroleh.

c. Scene Kamera Augmened Reality

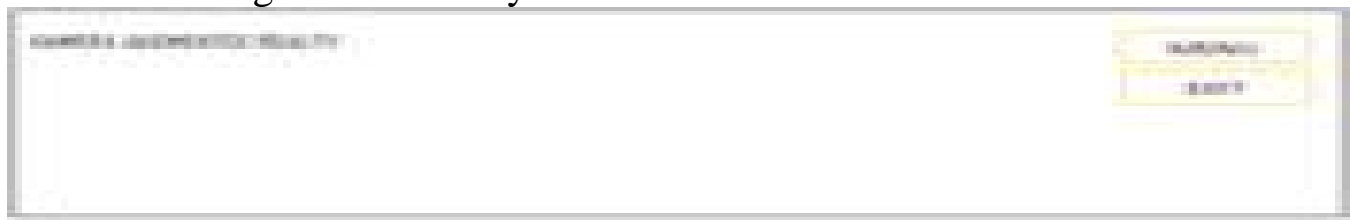

\section{Gambar 3 Desain Menu Kamera AR}

Menu kamera AR ini digunakan untuk mengidentifikasi marker menggunakan kamera HP (Smartphone).

d. Hasil Validitas, Reliabilitas dan Uji coba media Augmented Reality

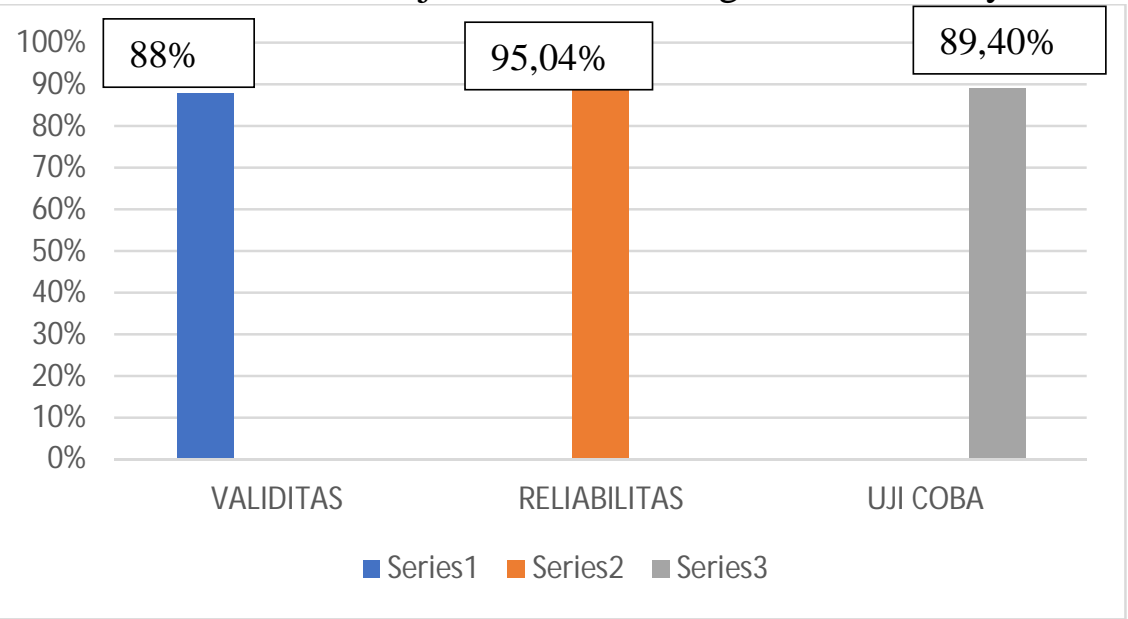

Gambar 4 Hasil Validitas, Reliabilitas dan Uji Coba 
Berdasarkan Gambar 4.4 diketahui bahwa sebelum produk yang berupa media pembelajaran Augmented Reality siap untuk digunakan tentunya melewati proses validitas dan reliabilitas untuk mengetahui seberapa valid dan reliabel media tersebut untuk digunakan. Selain itu juga melewati tahap uji coba produk kepada responden yakni mahasiswa Teknik elektro.

e. Hasil Rincian Uji Coba Produk

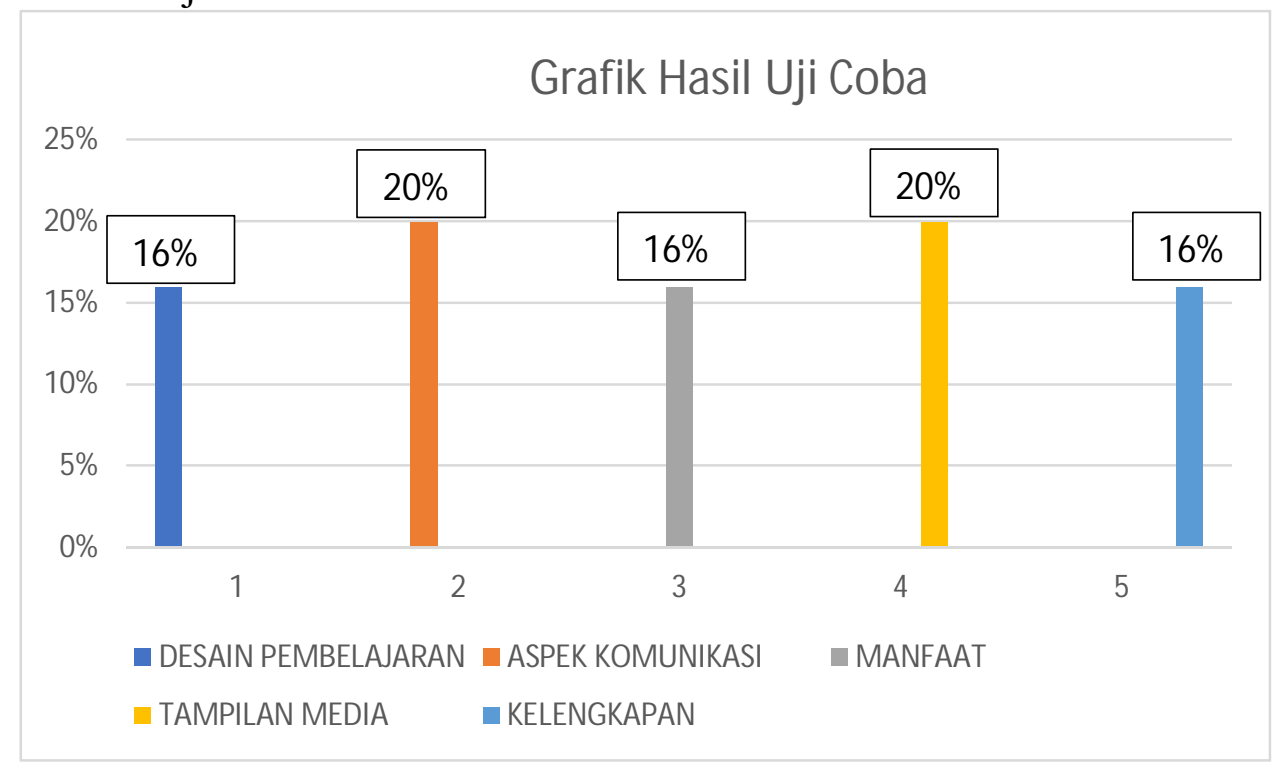

\section{Gambar 5 Grafik Hasl Uji Coba}

Berdasarkan Gambar 4.4 diketahui bahwa dalam penelitian ini indikator yang digunakan untuk menilai produk AR ada 5 point yaitu Desain pembelajaran, Tampilan Media, Aspek komunikasi, Kelengkapan, dan Manfaat.

\section{Pembahasan}

Dari hasil Analisa data dapat diketahui bahwa pengembangan aplikasi media pembelajaran Augmented Reality layak untuk digunakan dalam matakuliah pengukuran listrik Baharudin (2017), Mareta (2015). Cara kerja aplikasi ini secara keseluruhan yaitu apabila materi yang memuat tentang aplikasi AR dibuka maka akan membuka kamera pada alat yang terpasang di smartphone. Kegunaan kamera ini untuk mendeteksi marker yang terdapat pada bagian materi, apabila kamera berhasil melacak marker maka akan menampilkan gambar 3D.

Dalam penelitian ini menggunakan 6 indikator yang dibuat sebagai acuan apakah aplikasi ini layak digunakan atau tidak. Hasil validitas menunjukan $88 \%$ dari 25 soal dan butir soal yang tidak valid sebanyak 3 sehingga yang layak untuk dipakai sebanyak 22 soal dan termasuk dalam kategori valid. Sedangkan untuk hasil reliabilitas sebesar 0,954/ 95,40\% yaitu diartikan bahwa media tersebut reliabel untuk digunakan. Begitu pula hasil uji coba produk yang dilakukan pada mahasiswa menunjukan bahwa respon mahasiswa menunjukan jika aplikasi AR layak untuk digunakan dalam matakuliah pengukuran listrik dengan hasil persentase secara keseluruhan yaitu $89,40 \%$ dan dapat diartikan valid dan sangat layak untuk digunakan. 
Penerapan media pembelajaran Augmented Reality mampu memberikan suasana pembelajaran interaktif kepada mahasiswa dikarenakan mampu memahami materi pembelajaran lebih detail dan teliti, [Hermawan (2015, Mantasia (2016)]. Keunggulan media pembelajaran Augmented Rality yang diterapkan dalam matakuliah pengukuran listrik yaitu mampu memberikan rangsangan terhadap pola piker mahasiswa bahwa pembelajaran tidak harus selalu konvensional melainkan dapat menyenangkan dan tidak membosankan dengan cara diterapkann pembelajaran yang dapat menampilkan 3D berbasis simulasi. Selain itu pengembangan teknologi AR mampu memenuhi kebutuhan peningkatan keterampilan mahasiswa untuk berkreasi, meningkatkan kognitif siswa untuk berpikir kritis serta memudahkan mahasiswa dalam memahami sesuatu hal yang abstrak dan kompleks.

\section{Kesimpulan}

Berdasarkan pembahasan hasil penelitian dapat ditarik kesimpulan bahwa media pembelajaran AR dapat digunakan sebagai media belajar pengukuran listrik pada materi komponen elektronik yang mampu memberikan kemudahan terhadap mahasiswa untuk memahami materi tersebut. Media pembelajaran Augmented Reality dapat dijadikan media belajar yang menyenangkan dan mampu menciptakan suasana yang baru dan ineraktif dalam pembelajaran mahasiswa Teknik elektro. Respon mahasiswa terhadap aplikasi AR sangat tinggi yang mampu meningkatkan antusias mahasiswa ketika proses pembelajaran berlangsung.

\section{Daftar Pustaka}

Mareta, A. 2015. Implementasi Media Ajar Bangun Ruang Berbasis Augmented Reality pada SMPN 2 Selomerto Kabupaten Wonosobo. Skripsi tidak diterbitkan. UNS. Semarang.

Baharudin, A. 2017. Pengembangan Media Pembelajaran Sugmented Reality pada Mata Pelajaran Dasar Elektronika di SMK Hamong Putera 2 Pakem. Skripsi tidak diterbitkan. UNY. Yogyakarta.

Hermawan , L.,Hariadi, M. Pemanfaatan Augmented Reality sebagai Media Informasi Kampus Menggunakan Brosur. Seminar nasional teknologi informasi dan komunikasi: 8188.

Mantasia. 2016. Pengembangan Teknologi Augmented Reality sebagai Penguatan dan Penunjang Metode Pembelajaran di SMK untuk Implementasi Krikulum 2013. Jurnal Pendidikan Vokasi. 6 (3): 281-291.

Ananda, T. 2015. Penerapan Augmented Reality sebagai Media Pembelajaran Mengenal Planet-Planet di Tata Surya. Jurnal Sistem dan Teknologi Informasi. 1 (1): 1-6.

Maulana, A. 2016. Aplikasi Augmented Reality sebagai Media Pembelajaran Tata Surya. Prosiding seminar ilmiah nasional computer dan sistem intelejen. 8 (1): 53-59.

Mantasia. 2016. Pengembangan Teknologi Augmented Reality sebagai Penguatan dan Penunjang Metode Pembelajaran di SMK untuk Implementasi Krikulum 2013. Jurnal Pendidikan Vokasi. 6 (3): 281-291.

Wulansari, O.2013. Penerapan Teknologi Augmented Reality pada Media Pembelajaran. Jurnal Informatika. 13(1): 169-179

Rusnandi.2012. Implementasi Augmented Reality pada Pengembangan Media Pembelajaran Bangun Ruang 3D untuk Siswa Sekolah Dasar. Infotech Jurnal: 24-31

Siswanto.2013. Perencanaan Alat Peraga 3D Belajar Mengenal Macam-macam Binatang Berbasis Augmented Reality di TK ABA 33 Semarang. Jurnal Teknik Informatika.: 1-9. 